Fourteen patients were assigned to receive amiodarone and 23 placebo. Two patients (one in each group) died before the end of the study.

Detection of autoantibodies - None of the patients treated with placebo had or developed autoantibodies. On day 1 none of the patients treated with amiodarone had detectable autoantibodies. On day 7 three of the 13 surviving patients treated with amiodarone had detectable antithyroid microsomal antibodies, and on day 30 six had them (55\%). Tests for all other autoantibodies yielded negative results in both groups.

Thyroid function-The table shows the serum concentrations of triiodothyronine, thyroxine, and thyroid stimulating hormone. No differences were seen in triiodothyronine and thyroxine concentrations between the two groups. A significant difference in concentrations of thyroid stimulating hormone between the two groups was noted on day $30(p<0 \cdot 05)$. In three patients treated with amiodarone the concentration of thyroid stimulating hormone rose to the hypothyroid range $(8 \cdot 3,8.6$, and $8 \cdot 8 \mathrm{mU} / \mathrm{l})$. Two of these three patients had antithyroid antibodies.

\section{Discussion}

The finding of thyroid antibodies in $55 \%$ of patients after they had been taking amiodarone for $\mathbf{3 0}$ days suggests that this drug has a toxic effect on the thyroid even when taken for fairly short periods. Previously such antibodies have been reported only in patients given long term treatment. ${ }^{3}$ Follow up evaluation six months after the withdrawal of amiodarone in the seven patients who had detectable antimicrosomal thyroid antibodies showed complete clearance of the autoantibodies. Similarly, concentrations of thyroid stimulating hormone in these patients reverted to normal. Thus the toxic effect seems to be reversible when the drug is used for short periods.

\section{References}

1 Blomgren SE, Condemi JJ, Bignall MC, Vaughan JH. Antinuclear antibody induced by procainamide: a prospective study. $N$ Engl $\mathcal{Y}$ Med 1969;281:64-6.

2 Pritchard DA, Singh BN, Hurley PJ. Effects of amiodarone on thyroid function in patients with ischaemic heart disease. Br Heart f 1975;37:856-60.

3 Martino E, Safran M, Aghini-Lombardi F, et al. Environmental iodine intake and thyroid dysfunction during chronic amiodarone therapy. Ann Intern Med 1984;101:28-34.

4 Borowski GD, Garofano CD, Rose LI, et al. Effect of long-term amiodarone therapy on thyroid hormone levels and thyroid function. Am $\mathcal{Y}$ Med 1985;78:443-50.

Roit IM, Donish D. Immunfluorescent lests for the detection of automibodies. Geneva: World Health Organisation, 1969:1-2.

(Accepted 18 November 1985)

\title{
Distinct IgG recognition patterns during progression of subclinical and clinical infection with lymphadenopathy associated virus/human $\mathbf{T}$ lymphotropic virus
}

\author{
JOEP M A LANGE, ROEL A COUTINHO, WILLY J A KRONE, LEO F VERDONCK, \\ SVEN A DANNER, JAN VAN DER NOORDAA, JAAP GOUDSMIT
}

\begin{abstract}
Longitudinal IgG recognition patterns of viral proteins were studied in 15 men who had seroconverted for lymphadenopathy associated virus/human T lymphotropic virus (LAV/HTLV-III). Antibodies to the major viral core protein $\mathrm{p} 24$, which is a cleavage product of the gag gene encoded precursor protein pr 55 , appeared first. These were soon followed by antibodies to pr55 and more gradually by antibodies to the other gag gene encoded cleavage product $\mathrm{p} 18$, the env gene encoded transmembrane glycoprotein gp41, the env gene encoded glycoproteins gp65 and gp110, and the putative pol gene product $\mathrm{p} 33$.

In 13 subjects who remained healthy the reactivity to the different proteins increased or stabilised with time, while in two men who developed acquired immune deficiency syndrome (AIDS) the reactivity, most noticeably to gag encoded proteins, diminished before or at the onset of symptoms.
\end{abstract}

Academic Medical Centre of the University of Amsterdam, Meibergdreef 15, 1105 AZ Amsterdam, the Netherlands

JOEP M A LANGE, MD, research fellow, department of virology

WILLY J A KRONE, PHD, biochemist, department of virology

JAN VAN DER NOORDAA, MD, PHD, virologist and head of department of virology

JAAP GOUDSMIT, MD, PHD, virologist, department of virology

SVEN A DANNER, MD, PHD, head of outpatient department and the AIDS unit of the department of internal medicine

Department of Infectious Diseases, Municipal Health Service, Amsterdam ROEL A COUTINHO, MD, PHD, virologist and head of department

Department of Haematology, Academic Hospital of the University of Utrecht, the Netherlands

LEO F VERDONCK, MD, PHD, haematologist

Correspondence and requests for reprints to: Dr Lange.

\section{Introduction}

Lymphadenopathy associated virus (LAV), ${ }^{12}$ also designated human T lymphotropic virus type III (HTLV-III) ${ }^{3}$ is the causative agent of acquired immunodeficiency syndrome (AIDS). IgG antibodies to LAV/HTLV-III are found in nearly all patients with AIDS or signs preceding AIDS, whereas they are virtually absent in populations not at risk. ${ }^{47}$ Furthermore, LAV/HTLV-III can be isolated from many subjects with AIDS or signs preceding AIDS, ${ }^{8}$ and transmission of the virus by blood transfusion has led to the subsequent development of AIDS..$^{10}$

In a Swiss seroepidemiological study Schüpbach et al found evidence for the following pattern of $\mathrm{IgG}$ antibody response in human LAV/HTLV-III infection: in early and asymptomatic infection antibodies to the gag gene encoded protein $\mathrm{p} 24^{11} 12$ predominate, whereas in later and symptomatic infection antibodies to the env gene product gp $41^{11} 12$ are found most consistently, and with progression to AIDS antibody titre to p24 declines or disappears. ${ }^{13}$

We present data on the protein recognition patterns of LAV/ HTLV-III in sequential serum samples from 15 individuals, two of whom eventually developed AIDS, that were followed from seroconversion to a maximum of three and three quarters years later.

\section{Subjects and methods}

Sequential serum samples obtained from 13 homosexual men who participated in a study of the efficacy of hepatitis B vaccine between 1980 and $1982^{14}$ and had seroconverted for LAV/HTLV-III ${ }^{15}$ were studied. Blood was collected at monthly intervals during the initial five months of the trial and every three months thereafter. In these 13 subjects the average time from the last serum sample that was negative for anti-LAV/HTLV-III to the first that was positive for anti-LAV/HTLV-III was 10.9 weeks (range $1-16$ weeks). One subject developed AIDS three years after seroconversion. Six men entered a new prospective study on AIDS, which started in October 1984. 
For the whole group the average length of follow up after seroconversion was $109 \cdot 5$ weeks (range 12-198 weeks).

Apart from this group two other subjects who had seroconverted were studied. One subject had seroconverted after receiving a blood transfusion and developed AIDS two and a half years later. The other person, whose clinical history has been described elsewhere, had a transient mononucleosis like illness two weeks after sexually acquired LAV/HTLV-III infection. ${ }^{16}$ Both subjects were followed up for 134 weeks after seroconversion.

\section{IMMUNOBLOT ANALYSIS}

Heat inactivated LAV/HTLV-III purified with a sucrose gradient was fractionated by electrophoresis using a $12 \%$ polyacrylamide slab gel in the presence of sodium dodecylsulphate. ${ }^{17}$ The protein bands on the gel were transferred to a nitrocellulose sheet $(0.45 \mu \mathrm{m}$; Schleicher and Schuell, and 2). Taking p24 recognition as point zero, we eventually recognised three other LAV/HTLV-III proteins in serum samples from all persons studied; pr55gag from 12 weeks on, gp4 $41^{\text {env }}$ from 40 weeks, and gp65env from 78 weeks (fig 2). Serum samples from 13 subjects eventually reacted with p18ga and $\mathrm{p} 33^{\mathrm{pol}}$ (fig 2). Pr110 env was recognised by serum samples from three subjects only, 20 weeks or more after seroconversion.

In one subject the precise time of LAV/HTLV-III transmission could be determined. ${ }^{16}$ Two weeks after a sexually acquired LAV/HTLV-III infection antibodies were not found, but four weeks after transmission his serum reacted (strongly) with p24, and later with other proteins.

\section{PROGNOSTIC IMPORTANCE OF IMMUNOBLOT PATTERNS}

In 13 subjects no serious persistent disease developed. The intensity of the protein bands either remained constant or increased in all these subjects

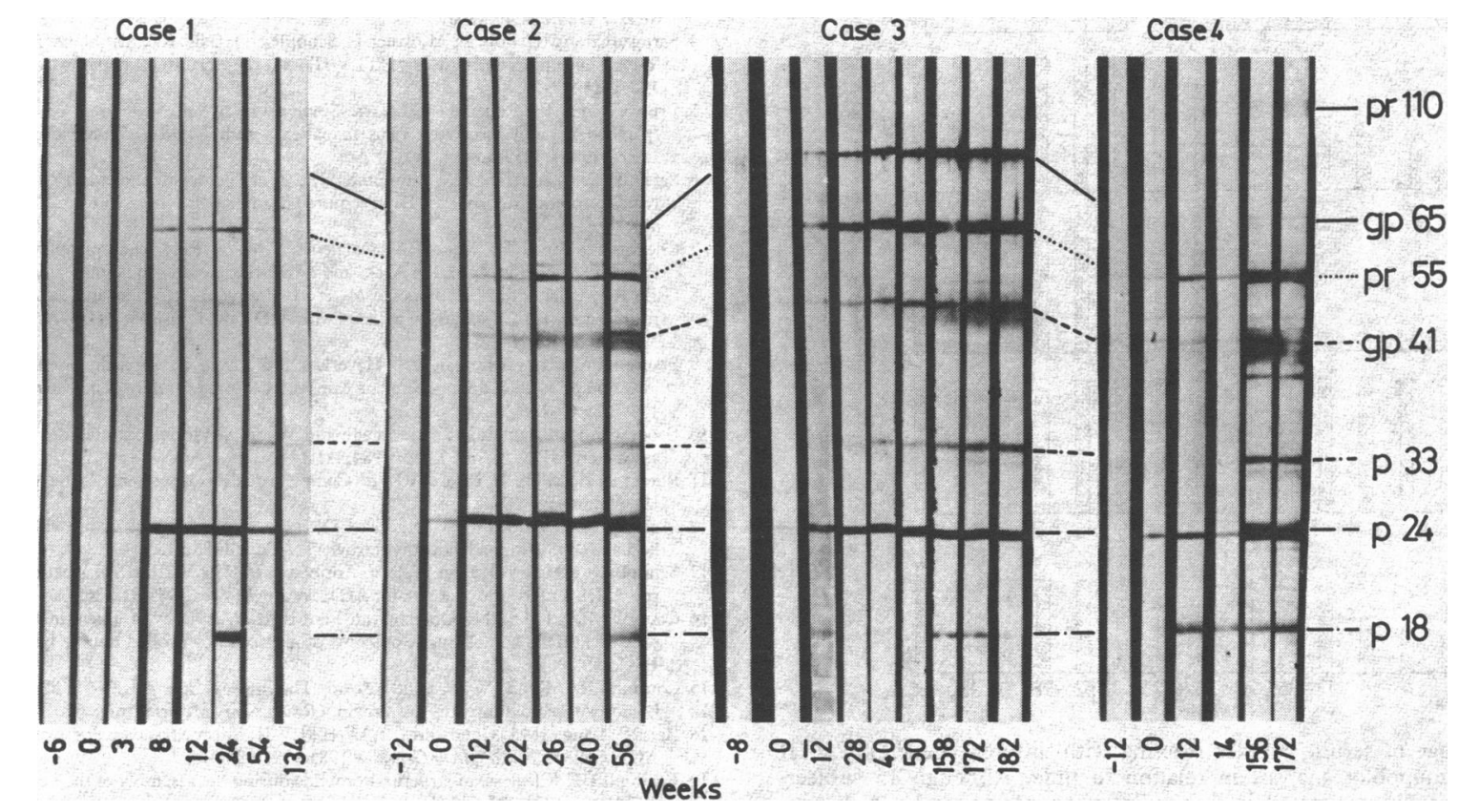

FIG 1-Immunoblot analysis of consecutive serum samples for antibodies to LAV/HTLV-III. Time of first immunoblot positive serum sample was taken as point zero. Subject in case 1 is a man in whom AIDS developed 130 weeks after seroconversion; subjects in cases 2 , 3 , and 4 are men without known lasting LAV/HTLV-III related symptoms.

Dassel, West Germany). ${ }^{18}$ After this transfer the sheet was rinsed with phosphate buffer saline and Tween $0.05 \%$ and incubated for two hours in phosphate buffer saline $(\mathrm{pH} \mathrm{7.4)}$ at room temperature. The sheet was then rinsed with phosphate buffer saline and Tween, dried, and stored at $4^{\circ} \mathrm{C}$ until use. When used the sheet was cut into strips and each strip preincubated for one hour at $37^{\circ} \mathrm{C}$ in $2.5 \mathrm{ml}$ phosphate buffer saline and Tween containing $4 \%$ normal goat serum. Subsequently $25 \mu \mathrm{l}$ of heat inactivated test serum was added to each strip separately, and incubation was continued for one hour at $37^{\circ} \mathrm{C}$. After washing with phosphate buffer saline and Tween the strips were incubated at room temperature for one hour with biotinylated goat antihuman IgG (Vector, Burlingame, California). After another washing the strips were incubated for one hour at room temperature with a preformed complex of avidin and biotinylated horse radish peroxydase (Amersham International, Bucks). After washing colour was developed using 4-chloro-1-naphthol as substrate. ${ }^{19}$

Proteins p18 $8^{\mathrm{gag}}$, p24gag, and pr55gag were considered to be encoded by the gag gene; proteins gp41 env, gp65env, and pr $110^{\text {env }}$ by the env gene, ${ }^{11}{ }^{12}$; and protein $\mathrm{p} 33^{\text {pol }}$ by the pol gene. ${ }^{20}$

\section{Results}

\section{PROTEIN RECOGNITION PATTERNS OF LAV/HTLV-III}

In all 15 subjects studied the first positive serum sample reacted with p24gag. Reactivity against pr55gag was also often detected at this time, whereas it usually took longer for the other proteins to be recognised (figs 1 throughout the observation period, even when this was longer than three years (cases 3 and 4 in fig 1 ).

In two subjects AIDS developed. One of these patient's clinical history has been described fully elsewhere. ${ }^{15}$ Two and a half years after seroconversion he developed AIDS related complex, and half a year later AIDS was diagnosed. At the time he developed AIDS related complex his immunoblot pattern did not show p24gag, while the only other protein that was clearly present before this time, gp4lenv, decreased in intensity but remained visible until his death over a year later. The second patient (case 1, fig 1) was a heterosexual man who received multiple blood transfusions in June 1982. Seroconversion for LAV/HTLV-III occurred in July 1982. Two years later malaise, fever, and weight loss developed. AIDS was diagnosed two and a half years after seroconversion when he developed candida oesophagitis. Examination of his last two serum samples, taken 54 and 134 weeks after seroconversion, showed a gradual diminishing in the intensity of the protein bands, especially of $\mathrm{p} 18^{\mathrm{gag}}$ and $\mathrm{p} 2 \mathrm{ggag}^{\mathrm{a}}$

\section{Discussion}

As found in studies of experimental infection in non-human primates $^{21}$ and in humans, ${ }^{22}$ we found that the early antibody response against LAV/HTLV-III was directed predominantly against gag gene products (especially p24 and pr55) and followed gradually by a response directed against env gene products (especially gp4l and gp65) and the pol gene product (p33). The earliest IgG response was directed against p24gag. In the subject in 
whom the precise time of LAV/HTLV-III transmission was known the lag time between infection and recognition of p24gag was between two and four weeks.

Not only did antibodies against p24gag indicate the early phase of LAV/HTLV-III infection but they also provided information in later infection. In subjects without AIDS the intensity of the

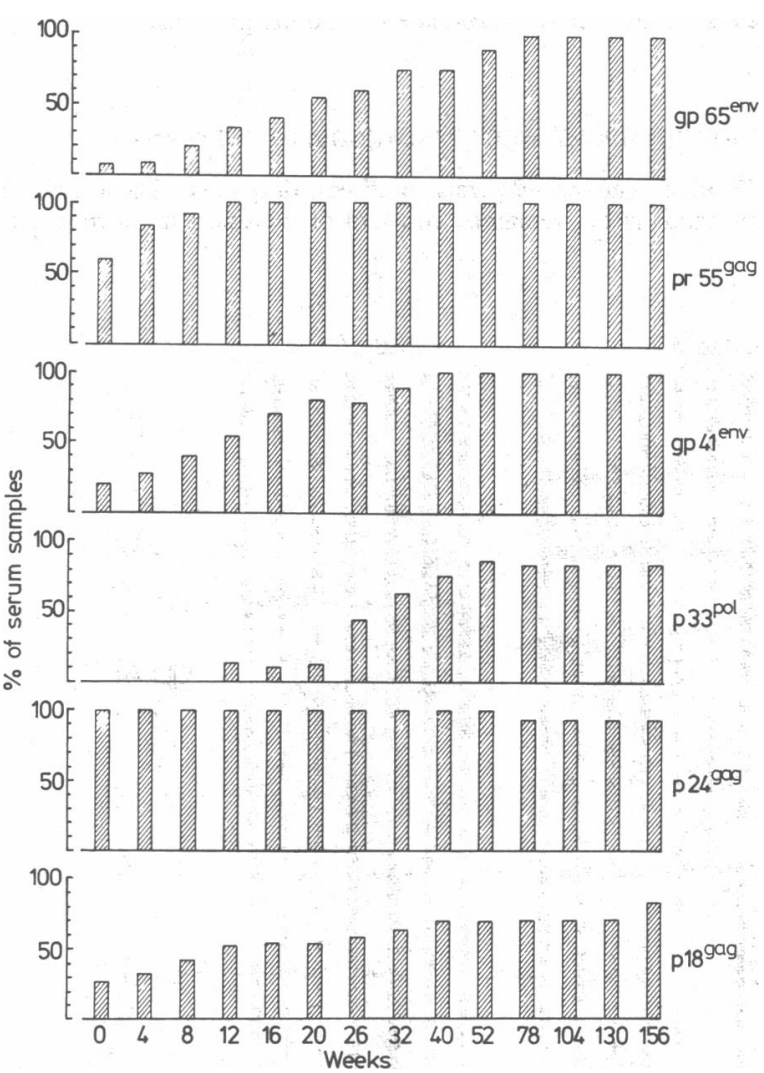

FIG 2-Percentage of serum samples reacting with different LAV/HTLV-III proteins by immunoblot analysis in relation to time. Although 15 subjects were studied not all were tested at each subsequent interval and not all were followed up for 156 weeks. At each interval shown, however, at least six subjects were tested.

response against all the different visible proteins stabilised or increased with time even when they were followed up for three years. As Biggar et al reported recently, ${ }^{22}$ we found in the two subjects in whom AIDS eventually developed that the intensity of the response against the different proteins started to diminish, most noticeably for gag encoded proteins, two and a half years and one year after seroconversion, respectively. In one of these patients total eradication of p24gag coincided with the onset of AIDS related symptoms, whereas gp $41^{\text {env }}$ remained visible to his death.

Schüpbach $e t$ al tentatively concluded from transsectional data that decline or loss of antibody titre to p24gag signifies impending transition to AIDS ${ }^{13}$; findings from our longitudinal study support this. Whether the decline of anti-p24gag titre is due to excessive production of viral antigen in progressive symptomatic LAV/ HTLV-III infection or to exhaustion of B cell lines producing anti$\mathrm{p} 24^{\mathrm{gag}}$, or both, has yet to be investigated.

\section{References}

1 Barré-Sinoussi F, Chermann JC, Rey F, et al. Isolation of a T-lymphotropic retrovirus from a patient at risk for acquired immune deficiency syndrome (AIDS). Science 1983;220:868-71.

2 Vilmer E, Barré-Sinoussi F, Rouzioux C, et al. Isolation of new lymphotropic retrovirus from two siblings with haemophilia B, one with AIDS. Lancet 1984;i:753-7.

3 Popovic M, Sarngadharan MG, Read E, Gallo RC. Detection, isolation, and continuous production of cytopathic retroviruses (HTLV-III) from patients with AIDS and pre-AIDS. Science 1984;224:497-500.

4 Sarngadharan MG, Popovic M, Bruch L, Schüpbach J, Gallo RC. Antibodies reactive with human T-lymphotropic retroviruses (HTLV-III) in the serum of patients with AIDS. Science 1984;224:506-8.

5 Brun-Vezinet F, Rouzioux C, Barré-Sinoussi F, et al. Detection of IgG antibodies to lymphadenopathy-associated virus in patients with AIDS or lymphadenopathy syndrome. Lancet 1984; ;:1253-6.

6 Safai B, Sarngadharan MG, Groopman JE, et al. Seroepidemiological studies of human T lymphotropic retrovirus type III in acquired immunodeficiency syndrome. Lancet 1984;i:1438 40 .

7 Cheingsong-Popov R, Weiss RA, Dalgleish A, et al. Prevalence of antibody to human Tlymphotropic virus type III in AIDS and AIDS-risk patients in Britain. Lancet 1984;ii:477-80.

8 Gallo RC, Salahuddin SZ, Popovic M, et al. Frequent detection and isolation of cytopathic retroviruses (HTLV-III) from patients with AIDS and at risk for AIDS. Science 1984;224:5003.

9 Feorino PM, Kalyanaraman VS, Haverkos HW, et al. Lymphadenopathy associated virus infection of a blood donor-recipient pair with acquired immunodeficiency syndrome. Science 1984;225:69-72.

10 Groopman JE, Salahuddin SZ, Sarngadharan MG, et al. Virologic studies in a case of transfusionassociated AIDS. N Engl f Med 1984;311:1419-22.

11 Ratner L, Haseltine W, Patarca R, et al. Complete nucleotide sequence of the AIDS virus, HTLVIII. Nature 1985;313:277-84.

12 Muesing MA, Smith DH, Cabradilla CD, et al. Nucleic acid structure and expression of the human AIDS/lymphadenopathy retrovirus. Nature 1985:313:450-7.

13 Schüpbach J, Haller O, Vogt M, et al. Antibodies to HTLV-III in Swiss patients with AIDS and pre-AIDS and in groups at risk for AIDS. N Engl F Med 1985;312:265-70.

14 Coutinho RA, Lelie PN, Albrecht-van Lent P, el al. Efficacy of a heat-inactivated hepatitis $B$ vaccine in male homosexuals: outcome of a placebo controlled double blind trial. $\mathrm{Br} \mathrm{Med} F$ 1983;286:1305-8.

15 Coutinho RA, Krone WJA, Smit L, et al. The introduction of LAV/-HTLV-III into the male homosexual community in Amsterdam. Genitourinary Medicine (in press)

16 Reiss P, Lange JMA, Goudsmit J. LAV/HTLV-III infectie na eenmalig sexueel contact met een AIDS patiënt. Ned Tijdschr Geneeskd 1985;129:1933-4.

17 Laemmli UK. Cleavage of structural proteins during the assembly of the head of bacteriophage T4. Nature 1970;227:680-5.

18 Towbin H, Staehlin T, Gordon J. Electrophoretic transfer of proteins from polyacrylamide gels to nitrocellulose sheets: Procedure and some applications. Proc Natl Acad Sci USA 1979;76: 4350-3.

19 Hawkes R, Niday E, Gordon J. A dot-immunobinding assay for monoclonal and other antibodies. Anal Biochem 1982;119:142-7.

20 Chang NT, Huang J, Ghrayeb J, et al. An HTLV-III peptide produced by recombinant DNA is immunoreactive with sera from patients with AIDS. Nature 1985;315:151-4.

21 Goudsmit J, Gibbs CJ, Asher DMA, Gajdusek DC. Extrathecal and intrathecal IgG response to the AIDS virus LAV/HTLV-III in experimental infection of chimpanzees. Cancer Detect Prev (in press)

22 Biggar RJ, Melbye M, Ebbensen P, et al. Variation in human T lymphotropic virus III (HTLVIII) antibodies in homosexual men: decline before onset of illness related to acquired immune deficiency syndrome (AIDS). Br Med $\mathcal{F}$ 1985;291:997-8.

(Accepted 9 December 1985)

\section{YEARS AGO}

A curious case of early puberty was shown by Mr. Bruce Clarke at the meeting of the Pathological Society on January 19th. A large muscular boy, apparently ten or twelve years old, came under treatment on account of bowing of the tibiæ due to rickets, and the parents made the astonishing statement that he was born on May 17 th, 1882, a statement subsequently confirmed by a reference to the birth-certificate preserved at Somerset House. He was three feet eight and a half inches high, and weighed four stone six pounds. There was some down on his cheek, and, though there was no hair on the chest or in the armpits, he was as hairy as a man about the pubes and in the perinæum. His penis was as large as a man's, and was noticed to be erect every morning, though the testicles were rather smaller than those of an adult. The pomum Adami was well developed, and his voice was cracked like that of a boy losing his "childish treble." The development of his brain, however, had not kept pace with the growth of his body, and his mental state was about that of a child of his years. The girth of the head round the occipital and frontal protuberances was twenty-one inches, which is certainly not very small for his bulk. It is interesting to note that, in spite of the great development of his sexual organs, he has never given any evidence of sexual desire, and that no seminal emissions are known to have occurred. The boy was the third child in a family of five, and he was bigger than the eldest child, who was over seven years old. He was suckled for nine months. At about one year of age he began to grow rapidly and to eat voraciously, so that nothing seemed to satisfy him. Hair began to grow on the pubes, and, before he was a year and a half old, he was as hairy as a man. At about that time this very rapid rate of growth ceased, and, since then, his mother thinks he has only grown with ordinary rapidity. Mr. Bruce Clarke performed osteotomy on the bowed tibiz, and the boy made a good recovery. A few cases are on record where puberty developed between the ages of two and three years, but $\mathrm{Mr}$. Clarke informs us that he has been unable to find any other case recorded where it developed before eighteen months of age

(British Medical fournal 1886;i:263.) 